\title{
Role of trade unions in the prevention of mobbing (or bullying)
}

\begin{abstract}
Modern social theory and practice agree that mobbing (or bullying) is one of the most radical forms of industrial conflict, producing long-term consequences in all aspects of corporate business and for the overall national economy. Research shows that employees are the primary and greatest of victims, which indicates a strategic interest for trade unions in fighting mobbing and insisting on the prevention of mobbing as a determinant of a company's development strategy. A single consequence of mobbing never occurs but there is a series of consequences which are related and which, therefore, have a cumulative effect in maximising the damage. In a broader sense, we may even refer to the political consequences, when referring to mobbing becoming so widespread that it provokes general discontent among employees and a disapproving response from the public. In any case, the damage caused by mobbing may be said to be 'ultimate' as it affects everyone in particular the victims but also, in the long-run, the mobber (or bully), the company and the whole of society.
\end{abstract}

Keywords: mobbing, bullying, trade unions, human rights, role of legislation, labour law, collective action, health and safety, industrial conflicts, employee motivation, social dialogue, social partnership

Introduction

Workplace bullying is the most severe form of the violation of labour, social and economic and fundamental human rights in general. It inflicts on its victims serious and permanent psychological and health damage, causing at the same time large-scale economic damage to the company or institution, as well as to the overall national economy. Nowadays, sociology and individual and social psychology have developed methods that may be used to express in numbers the economic damage caused by workplace bullying - a phenomenon otherwise known as mobbing. On the whole, it occurs in such settings in which interpersonal relationships have already become disturbed, and where social democracy and positive communications among employees, and between employees and management, are not well developed. Particularly dangerous are covert, sophisticated mobbing mechanisms that destroy the healthy tissue of a company and the entire society.

It is, therefore, not only morally compelling but of economic interest to all those who partake in industrial relationships - government, employers and trade unions that they create and implement a joint strategy to fight against mobbing. In that respect, the legal and factual mechanisms of the prevention of mobbing hold primary interest. 
In this area, unions have a highly complex, demanding and special role. This role stems from the basic social function of a trade union, which is the affirmation and efficient protection of the labour, economic and social rights of employees. In that sense, the situation in terms of mobbing represents a basic test of the true social power of a union within a company (or institution) and within society at large.

In opposing instances of mobbing, the union exercises its role in three directions: advocating the enactment of comprehensive and humane labour and social legislation; constructing instruments of social partnership and peace; and strengthening its own overall social power.

\section{Legal mechanisms for the prevention of mobbing}

In the process of combating all forms of the violation of labour, economic and social rights, including mobbing, a very important role is given to the labour and social legislation which exists at the national level, as well as to international legal and political standards. These include, most importantly, the International Covenant on Economic, Social and Cultural Rights of the UN; the conventions and recommendations of the International Labour Organization; the European Social Charter; etc. National labour and social legislations, including the labour and social legislation of Serbia, is built on the specifics of documents such as these. In other words, efficient legal remedies in the prevention of mobbing may be instituted only within a comprehensive, humane and democratic labour and social legislation (Sunderić, 2006).

Concerning specific legislative initiatives on the prevention of mobbing, it should be noted that only nine countries in Europe, Serbia among them, have a special law on the prevention of mobbing. Other countries define legal mechanisms concerning the prevention of mobbing within their labour law legislation. Different views exist with regard to the advantages and drawbacks of the enactment of a special law on the prevention of mobbing. Practice has proved, however, that such a law, particularly in countries in transition, where social democracy is under-developed, offers a wide array of advantages. That it was trade unions in Serbia who initiated the adoption of this law, and that it was one of few points of agreement among otherwise divided and conflictual unions, speaks in favour of the establishment of such a law.

In the same fashion, the EU, with the active participation of the European Trade Union Confederation, has adopted EU Framework Directive 89/391/EEC on Safety and Health at Work. This defines basic measures for encouraging and applying the principles of health and safety in the workplace; the role of employer and employee in the process; the principles related to risk prevention in the workplace; and principles concerning the availability of information, consultation and the training of employees and their representatives, as well as the basic means of applying these specified principles. The statement by the European Commission to the European Parliament (in February 2007) under the heading The Improvement of Quality and Productivity at Work was the cornerstone of the EU's 2007-2012 Strategy. Within the EU setting, we may witness a myriad efforts with the specific goal of preventing mobbing.

Directive 89/391 raises the bar of the responsibility of employers in the area of protection in the workplace 'in every aspect of work'. 
Resolution A5-0283/2001 of the European Parliament recommends that the member states of the EU modify their respective legislations to include the phenomena of mobbing and sexual harassment in the workplace. According to the Resolution, the most successful approach on the path to achieving this is to harmonise a definition of the term 'mobbing'.

The European Parliament Report on Harassment in the Workplace (2001/2339 INI) defines certain responsibilities for the Committee on Employment and Social Affairs. In addition, the Report includes a recommendation of the Committee for Women's Rights and Gender Equality, addressed to the member states, to impose on the public and private sectors and the social partners the duty to define a policy in the prevention of mobbing, to provide experience exchange systems and to set forth solutions for the issues of harassment and repeated violence. The Committee recommends the development of a training programme for employees, managers, the social partners and medical doctors working in both the public and the private sectors (Lubarda, 2007).

The Committee further recommends the idea of appointing a mediator in the workplace (mediators may serve as a 'buffer zone' for employees). Council Resolution dated 3 June 2002, referring to the Community Strategy on protection in the workplace (2002/ C 161/01), states that the Council finds the enlargement process to be the greatest challenge facing the Union. It is further specified in the Resolution that the official and effective harmonisation of the legal heritage in the field of protection at work is of great importance, as is the addressing by the Community authorities of consultation, analysis and studies of information through the experience of the Advisory Committee on Safety and Health at Work of the European Agency for Safety and Health at Work (Bilbao) and the European Foundation for the Improvement of Living and Working Conditions (Dublin). In order to develop a prevention culture, it is necessary to include all the basic principles of protection into the education process and all future training programmes, as well as to improve campaigning designed to raise awareness.

Thus far, a majority of surveys have showed an alarming increase in psychological abuse at work. According to the Fourth European Working Conditions Survey (2007), published by the European Foundation for the Improvement of Living and Working Conditions, $5 \%$ of workers reported that they had been victims of violence and harassment in a 12-month period. The result of the survey was that the European partners signed a Framework Agreement on Harassment and Violence at Work, while the European Commission, within the EU Strategy for Health and Safety 2007-2013, stressed the importance of mental health at work. Some EU member states (particularly Sweden) have adopted specific legislation in the field of mobbing, while other countries are in the process of creating it, with drafts already in existence (e.g. Italy). An increased influence of mobbing on conditions within the workplace is now a motive for the social partners to include this phenomenon in collective agreements and codes of conduct.

Two of eight international labour standards (part of the Code of Conduct with reference to the respect for working conditions in the textile industry supply chain) require the prohibition of discrimination in the workplace and special protection for employees at work. The second standard (adapted from Conventions No. 100 and 111 of the International Labour Organisation) prohibits, in particular, any form of discrimination, while the seventh standard (adapted from the Conventions on Preventing Major In- 
dustrial Accidents, No. 174, and on Safety and Health in Mines, No. 176) states explicitly that abuse, threats and the use of physical force, atypical forms of punishment and discipline, the making of sexual and other threats and intimidation by the employer in the workplace are prohibited.

The Constitution of the Republic of Serbia has provisions on the prohibition of discrimination, as specified in Article 21 where it is declared that the Constitution and the law are equal. Every citizen is entitled to equal legal protection, without discrimination. Every form of indirect or direct discrimination based on particular reasons which may, in particular, be race, gender, national origin, social origin, birth, religion, political or other attitude, property status, culture, language, age, mental or physical disability - is prohibited.

In Article 22, all people are guaranteed the right to judicial protection whenever their human or minority rights, as guaranteed by the Constitution, are violated or denied and such people are entitled to indemnities in the event of the violation of their rights. Citizens may turn to international institutions for the purpose of protecting the freedoms and rights guaranteed to them by the Constitution.

Certain provisions of the Labour Act refer to direct and indirect discrimination, and the bullying and sexual harassment of employees and people seeking employment, on the basis of their personal features, status and background, as well as to discrimination against people who may not file an action for the recovery of damages in a state court as provided by the Contentious Proceedings Act. This element provides a form of protection for employees and people seeking employment in such cases of them being discriminated against because of their personal features. The Labour Act of the Republic of Serbia may govern the right of employees to health protection and personal integrity, as well as a number of other rights, but it does not, however, provide efficient and effective protection to employees in all cases of violence at work.

Article 12 of the Labour Act provides that an employee is, inter alia, entitled to safety and the protection of life and health at work, as well as to the protection of their personal integrity. Article 21 of the Act explicitly prohibits bullying and sexual harassment. Under the Act, bullying is defined as any form of undesirable behaviour caused on such grounds as specified in Article 18 (referring to the prohibition of discrimination), where the behaviour aims to violate the dignity of a person seeking employment or an employee, thereby generating a hostile, humiliating and insulting work environment. Sexual harassment, under this Act, represents any form of verbal, nonverbal or psychological treatment aimed to violate the dignity of an employee or someone seeking employment. Article 23 provides that, in the event of discrimination with reference to Articles 18-21, either a person seeking employment or an employee may file an action for the recovery of damages in a court of jurisdiction pursuant to the Act.

However, actual practice in all countries in transition, including Serbia, has confirmed that the adoption of high-quality regulations is not enough, as it is necessary for members of society to be motivated and to have sufficient room to implement such regulations. This is particularly obvious when it comes to such delicate issues as the gross violation of human dignity and the labour and economic rights of employees. In that respect, the true social power of trade unions to recognise different instances of 
mobbing, and successfully to combat these by the strength of their action, comes into view.

\section{The economic, social and moral causes and consequences of mobbing}

Modern social theory and practice agree that mobbing is one of the most radical forms of industrial conflict, producing long-term consequences in all aspects of corporate life as well as in the overall national economy. It is difficult to assess which side sustains more damage in the long-run. Research does show, however, that employees are the primary and the greatest of the victims, which implies a strategic interest for trade unions in fighting mobbing and, in such a context, to insist on the prevention of mobbing as a determinant of a company's development strategy.

The economic, social and moral causes and consequences of mobbing are intertwined and are mutually and conditionally dependent. This interconnection and conditionality may be put into the context of an old Serbian folk which says 'He who doesn't pay on the bridge will pay for the bridgework'. To be specific, what is missed when organising work, drafting a development strategy and a company's business policy (i.e. when defining clear rules of behaviour acceptable to all parties and developing and reaffirming the conscience and responsibility of both the social partners - employers and employees - for their mutual interests within a company or institution) will eventually lead to problems in business operations as well as a deterioration in interpersonal relationships, the development of distrust and the building of a barrier, or wall, between management and employees. In itself, this is, or may be, a source of mobbing. ${ }^{1}$

In order to analyse the consequences of mobbing for the purposes of prevention, it is of course essential to look into the causes, either beforehand or simultaneously with the consequences. In this way, one has to bear in mind the experience and the facts learned from earlier research studies which highlight that a single consequence of mobbing never occurs but that there is a series of consequences which are related and which, therefore, have a cumulative effect in maximising the damage caused by mobbing. In a broader sense, we may even talk of the political consequences, or the political damage, caused by mobbing. This primarily refers to situations when mobbing becomes so widespread that, coupled with other forms of the violation of the labour, economic and social rights of employees, it provokes a general discontent among employees and a disapproving response from the public. In any case, the damage caused by mobbing may be said to be 'ultimate' as it affects everyone - in particular the victims but also, in the long-run, the mobber, the company and the whole of society.

Mobbing leaves severe and persistent economic, political and social consequences for individuals, companies and society. When distrustful of the work environment, employees and managers can always be a source of distrust and dissatisfaction within overall society. Mobbing and its consequences, of course, affect mostly those societies that are economically and technologically under-developed-i.e. societies in transition. However, mobbing has a global character as it affects even economically and techno-

1 Crisis and Development - a collection of papers from an academic conference of the same name, Social Studies Institute: Belgrade, 2008. 
logically advanced countries where standards of quality and the practices of social democracy are well established. Speaking in favour of that are the results of an empirical research into mobbing conducted in EU member states in 2009, according to which:

- three million employees in the EU (or $2 \%$ ) have been the target of physical or sexual violence in the workplace

- twelve million employees (or $8 \%$ ) have been subject to various forms of mobbing

- employees affected the most are from Great Britain, the Netherlands and Finland, followed by those from Sweden, France and Ireland

- among new EU member states, mobbing occurs most of all in Lithuania, the Czech Republic and Slovakia

- it is estimated that mobbing costs EU states several billion Euros a year

- $54 \%$ of employees responded to long-lasting mobbing by putting up with it while looking for another job; $28 \%$ quit their job and looked for another; and $12 \%$ reported their employer

- $84 \%$ of those examined answered 'yes' to the question as regards whether they had ever been in a situation where their fellow workers, subordinates or superiors had psychologically harassed them

- $97 \%$ of those examined believe that this phenomenon is not widely-enough discussed

- 41.2 million employees in EU member states (or $28 \%$ ) claim that they find their job stressful and damaging to their health

- $44.5 \%$ of employees report having mental issues as a result of their job

- $68 \%$ of employees in the private sector and $53 \%$ of employees in the public sector would like to change their job. ${ }^{2}$

It has already been noted that any problems in business - such as unfavourable business results and poor work organisation or interpersonal relationships - represent potential causes of mobbing. The results of research, however, point to the following most frequently occurring causes:

- management failures

- inadequate management behaviour

- the limits of authority not being clearly defined

- bad information

- a poor work environment ruled by malice, envy and hostility.

Mobbing tends to begin with a conflict arising between a mobber and the victim, with the latter opposing the behaviour of the mobber, considering this to be unacceptable.

Defining mobbing through behaviour, intention and consequences offers the option of personalising mobbing and establishing in every single case not only if an employee is a victim of mobbing, but the amount of compensatory damages they should be paid.

The patterns of behaviour that may lead to mobbing, and which should be avoided, are specified in the established Rules on the Conduct of Employers and Employees Concerning Prevention and Protection against Mobbing. These patterns may be classified into six groups:

2 EUROSTAT, Brussels, 2009. 
- behaviour referring to the inability of proper communication

- behaviour harmful to well-established inter-personal relationships

- behaviour which is harmful to the personal reputation of employees

- behaviour which is harmful to employees' professional integrity

- behaviour harmful to employee health

- behaviour that may be considered to be sexual harassment.

What is the most frequent pattern of behaviour which is observed in a mobber and how may a victim of mobbing be identified?

A victim may be forced to do tasks for which they are not properly trained, or 'cluttered' with work or not given assignments, or constantly and unreasonably moved from one post to another and exposed to constant criticism or remarks; the victim may be subject to very close scrutiny and control; information required by the job may not be delivered to the victim; different stories may be made up about their lives; the victim may be ridiculed, gossiped about, not allowed to talk or interrupted during conversations; any verbal or non-verbal contact with the victim may be rejected; or they may be exposed to constant attacks by the mobber in many other ways.

According to numerous surveys conducted by psychologists, a certain pattern in the response of victims to mobbing may be observed. The first reaction is self-accusation: victims reflect on events, blaming themselves, often feeling embarrassment, as they may believe themselves to be incompetent and solely responsible for the fault that lead to them being treated with hostility and scorn. Victims therefore 'clam up' and are unwilling to talk about what they go through, thinking less of themselves. If the mobbing continues, a change in socio-emotional balance may occur in the victim, resulting in depression, anxiety, loss of interest in the self and others - family and friends - and provoking changes in the psycho-physical balance that may cause headaches, tachycardia, gastric disorders, etc., as well as behavioural disorders, particularly aggression that may cause victims to retreat into lethargy and isolation.

Mobbing victims decide to isolate themselves from work by using increasingly frequent sick leave and, if the mobbing continues for an extended period of time, they may be forced to quit their job. Apart from the loss of social status, victims suffer due to the loss of economic status as well.

At the same time, the employer in which mobbing has occurred also suffers damage, as the work process is not functioning properly and the organisation of work clearly has particular issues, while the damage that the employer may sustain due to sick leave or possible compensatory damage claims is not negligible. The question also arises regarding the bad reputation of a company in which employees are being harassed.

In a broader context, mobbing is harmful to the community at large as a result of the increase in medical costs or early retirement.

\section{Elements of a trade union strategy for the prevention of mobbing}

In the sphere of the fight against mobbing, an important place must be given to issues concerning prevention. Particularly important preventive measures which may be applied are as follows: 
- informing and educating employees on mobbing and its consequences

- the existence of a process of the constant vertical exchange of information

- the professional training and education of all employees

- mastering by management of the skills of good business communications and conflict-resolution techniques, as well as the recognition of behaviour that may be considered as mobbing

- the optimal arrangement of the work environment and working hours

- the promotion of a culture of respect for human dignity

- the discouragement of any form of psychological violence

- the inclusion in collective agreements of provisions that refer to mobbing and which establish fines in the event of such behaviour.

It is in the interests of the employer to apply preventive measures in order to create a good working atmosphere, which is essential to achieving the goals of the business. Conflicts that occur are unavoidable, although they must not be allowed to turn into radical forms of industrial and social conflict, or the permanent destruction of interpersonal relationships that will consequentially lead to mobbing (Kulić, 2008).

Informing and educating employees is one means of preventing mobbing (Mihailović et al. 2007). It is necessary, however, to inform and educate the entire public, including those who are not employed but who will seek and find appropriate employment upon the completion of schooling. It is beyond any doubt that the electronic and print media are indispensable when it comes to informing the public; however, the topic of mobbing needs also to be included in the education system and on school curricula.

The starting point for a definition of the role and responsibilities of trade unions in the prevention of mobbing lies in the protection and promotion of the collective and individual rights and interests of employees, meaning their labour and labour-related rights. This is the basic role essential to any trade union which is founded on the primary principles of union organisation and activism. The role of unions in the protection of employees' rights is multiple, and it reflects the protection of the labour, economic, social and professional interests of those employees who are voluntary union members. Unions are independent (of employers, associations of employers, authorities and political parties and organisations) in the expression, advocating and protection of the specific interests of their members. This primarily refers to the following issues:

- the conclusion and application of collective agreements

- making proposals and initiatives to adopt or amend regulations governing the position of employees in certain industries

- protection of employees' rights and interests in company privatisation procedures, as well as changes in status and organisation

- resolving issues of redundancy, liquidation, safety and the protection of labour and labour-related rights

- the provision of legal aid

- preparing methods of union struggle as well as other activities defined in the union rules. 
In order to accomplish their role, unions employ all methods of union activism and struggle, ranging from co-operation, negotiation, pressure on employers, criticism and challenging via the organisation of rallies and strikes.

An important aspect of trade union activism in prevention, and particularly in cases of mobbing, is the free-of-charge provision of legal aid and legal labour and labourrelated protection for union members, which is how it is possible to protect the rights of employees who become entitled to such aid by joining a union. Such specified activities are directed towards a consistent application of the Labour Act, and the conclusion of collective agreements with the basic goal of stopping the derogation of employees' rights; enabling the implementation of labour rights; strengthening levels of co-operation with labour inspection services; protecting union activists as regards their respective employers; and encouraging the peaceful resolution of collective disputes via the participation of the social partners.

The legal basis for the provision of legal labour protection for employees in the Republic of Serbia may be found in:

- the ratified conventions of the International Labour Organisation

- the European Social Charter (still to be ratified in Serbia)

- the Constitution of the Republic of Serbia

- the Labour Act

- specific regulations, such as, inter alia:

- Act on the Socio-Economic Committee

- Act on the Peaceful Settlement of Labour Disputes

- Act on Safety and Health at Work

- Act on Strikes

- the rules and programme of the trade union.

Among the Conventions and Recommendations of the International Labour Organisation, which sets down the legal basis for the provision of legal labour protection for employees, those that should be noted in this context are as follows:

- Convention No. 87 on Freedom of Association and Protection of the Right to Organise

- Convention No. 98 on the Application of the Principles of the Right to Organise and to Bargain Collectively

- Convention No. 135 on the Protection and Facilities to be Afforded to Workers' Representatives in the Undertaking

- Workers' Representatives Recommendation No. 143.

Experience in EU member states and in countries in transition confirms that a successful struggle against mobbing and its detrimental consequences is in direct proportion to the quality of the prevailing labour and social legislation.

\section{Collective bargaining}

Collective bargaining, a complex and conflicting process of the harmonisation of the interests shared by employees and their unions, on the one hand, and employers on the other, represents an important and, above all, preventive instrument of social democracy in terms of delivering protection against mobbing. In general, companies 
where the system of collective bargaining exists are exceptions to occurrences of mobbing or other forms of the violation of labour, economic and social rights and the disruption of inter-personal relationships. This is due to collective bargaining being based on the principles of the freedom of association of employees and employers, the autonomy of negotiators and those of good faith, which implies a minimum of mutual trust between negotiators (Feiertag, 2000). This minimum of trust that negotiations, as a form of social relationship, cannot do without is based on the awareness of employees and employers that there are mutual interests between them - i.e. the achievement of successful business results and surviving in an increasingly demanding market - and that, to accomplish this mutual interest, both parties have to share their responsibilities. This is exactly where the mutual interest in the prevention of mobbing lies.

In this regard, collective agreements in a large number of European countries are arranging mutual preventive measures to eliminate mobbing and this good practice is, slowly, being transplanted to Serbia.

Such an importance of collective bargaining and collective agreements, specifically their significant capacity to prevent instances of mobbing, comes from the collective bargaining process representing a key instrument in so-called autonomous labour legislation, the application of which is not based on the enforceability of the law but on consensus between the parties to a collective agreement. Of course, the power of what is willingly accepted by all participants in such a process is much stronger in any human relationship, as this always implies a greater motivation and responsibility to implement what has been adopted. It may, however, be assumed that the collective bargaining system is effectively established at all levels - in companies and institutions, as well as in industries and across business activities - and that collective agreements are based on a minimum of mutual concepts and goals.

\section{Social dialogue}

Social dialogue also has an important role to play in combating mobbing. This stems from the very definition of social dialogue, as the most complex and comprehensive form of social partnership through which the social partners - government, employers, employees and trade unions - define their mutual interests at all levels of social organisation. The crowning point of such a process is participation in, and influence on, the definition and monitoring of the implementation of strategies which are dedicated to the technological and socio-economic development of society from the perspective of the affirmation and protection of the role of labour in that process.

In this respect, social dialogue may be defined as a bridge between industrial democracy, which is implemented in companies through the rights of employees to receive information, to be consulted and to participate in decision-making through their labour, economic and social rights, through union activism, on the one hand; and the process of political decision-making (the adoption of laws and other regulations, economic policy, etc.) on the other. This means that social dialogue is essentially a new process that, in an adequate manner, immerses trade unions and other social organisations into the political life of society (Kohl, 2009).

Social dialogue is of particular importance in fighting mobbing from the perspective of the possibilities it creates of promoting suitable legal regulations on the issue, as 
well as establishing democratic, humane, labour and social legislation in general. At the same time, it facilitates opportunities for the three social partners mutually to take such steps and measures which, through the development of the concept and practice of building the social peace, construct also the most efficient preventive structure against mobbing.

\section{References}

Crisis and Development Collection of papers from an academic conference of the same name, Social Studies Institute: Belgrade, 2008.

EUROSTAT: Brussels, 2009.

Feiertag, G (2000) Collective Bargaining in Europe ETUI: Brussels.

Kohl, H (2009) Freedom of Association, Workers' Rights and Social Dialogue in Central Eastern Europe and in the West Balkans FES: Belgrade.

Kulić, Z (2008) Industrial Relationships Megatrend University: Belgrade.

Lubarda, B (2007) European Union Labour Law CID: Podgorica.

Mihailović, S, Z. Stojiljković and G. Ivanić (2007) Trade Union Barometer 2003, 2004, 2007 UGS Nezavisnost.

Šunderić, B (2006) Law of the International Labour Organisation Faculty of Law: Belgrade.

'Constitution of the Republic of Serbia' Official Gazette Belgrade.

'Labour Act of the Republic of Serbia' Official Gazette of the RS: Belgrade. 